\author{
木須 博行 ${ }^{* 1}$, 我 圭明 ${ }^{* 1}$, 成 勇勲 ${ }^{* 2}$

\section{The influence of measurement error on identification of bending regidity of beam and its stabilizing}

\author{
Hiroyuki KISU*1, Guiming RONG*1 and Yonghoon Sung ${ }^{* 2}$ \\ ${ }^{* 1}$ Faculty of Engineering, Nagasaki University \\ *2 Graduate School of Nagasaki University
}

Key Words : Inverse problem, Discrete Integral Method, Bending regidity, Boundary Element Method

\section{1. 緒 言}

著者らは推定対象の先験的情報が不要な逆問題の新 たな解析法 ${ }^{(1)(2)}$ を提案している。前報ではたわみの観 測值からはりの曲け䣓性分布を推定する方法を構成し た。その際、観測値に誤差が含まれない場合を示した が、実際には誤差の存在を前提とした推定法の確立が 必要となる。本論文は、測定誤差が存在する時の同定 解の挙動を定量的に調べるとともに、同定解が不安定 になる現象を解決する安定化処理について報告するも のである。

\section{2. 問題の殷 定}

2.1 境界要少法による逆問題の定式化 すでに 前報(2)で示したが、本研究における逆問題の定式化は 以下のようにまとめることができる。まず、曲け剛性 $E I(x)$ の一定でないはりの曲け問題の支配方程式は、 長手方向の座標を $x$ とすると式となる。

$$
\frac{d^{2}}{d x^{2}}\left(E I(x) \frac{d^{2} W}{d x^{2}}\right)=q(x)
$$

ここにWはたわみ、 $q(x)$ は外荷重である。

さらに、EIの分布を次式のようにテルタ関数を用 いた関数近似法を用いて表現する。

$$
\frac{d^{2}}{d x^{2}} E I(x)=\sum_{i=1}^{m} P_{i} \delta\left(x-x_{i}\right)
$$

ただし、 $\delta$ は Dirac のデルタ関数、 $P_{i}$ はデル夕関数の 強度、 $x_{i}$ はその作用点の座標、はその個数である。剛 性分布 $E I(x)$ が未知の場合、式 (2)においては、 $P_{i}$ が

* 原稿受付

*1 長崎大学工学部機械システム工学科

*2 長崎大学大学院

Email: kisuenet.nagasak1-u.ac.jp
末知数となる。この方法を採用する理由は、1. 通常 の 1 次要素による関数近似では 2 階微分すると 0 とな り、意味をなさなくなること、2，積分が単なる積和 で得られるようになること、の 2 点である。

重み関数を $W^{*}$ として、式 (1) を部分積分し、式 (2) を用いると最終的に次式が得られる。

$$
\begin{aligned}
W(s) & E I(s)=\left[Q W^{*}\right]_{0}^{L}-\left[M \frac{d W^{*}}{d x}\right]_{0}^{L}-\left[\theta E I(x) \frac{d^{2} W^{*}}{d x^{2}}\right]_{0}^{L} \\
+ & {\left[W \frac{d}{d x}\left(E I(x) \frac{d^{2} W^{*}}{d x^{2}}\right)\right]_{0}^{L}-\sum_{i=1}^{m} W\left(x_{i}\right) P_{i} \frac{d^{2} W^{*}\left(x_{i}, s\right)}{d x^{2}} } \\
& -2 \int_{0}^{L} W(x) \frac{d}{d x} E I(x) \frac{d^{3} W^{*}}{d x^{3}} d x+\int_{0}^{L} q W^{*} d x
\end{aligned}
$$

ここに、 $Q$ はせん断力、 $M$ は曲げモーメント、 $\theta$ は たわみ角である。本論文において設定した逆問題とは、 上式を利用して、たわみ $W$ を観測して曲け剛性 $E I$ の 分布を求めることである。ただし、曲け剛性 $E I$ その ものではなく、式(2)におけるデル夕関数の強度 $P_{i}$ が 求まることになる。すなわち、次式のような連立一次 方程式が構成される。

$$
\mathbf{A P}=\mathbf{b}
$$

ここに、係数マトリクス $A$ は $m \times m$ の正方行列、Pは $P_{i}$ を末知数とするべクトルである。これを解いた後に 式(2)よりEIの分布が得られる。

\section{3. 測定誤差の影響と安定化処理}

前報で示したように、たわみの観測値に関して、測 定誤差がないとした場合、先駼的情報の仮定なく、十 分な精度で曲け剛性分布を推定できた。しかし、たわ みの測定値に誤差がある場合、推定解がどのような影 響を受けるか、十分な検討が必要である。 
ここでは段つきはりの同定問題について記す。長さ 10 の単純支持梁に、大きさが 10 の集中荷重が中央点 に作用するはりの問題を設定した。はりの剛性分布 は、区間 $0 \leq x \leq 2.5$ と $7.5 \leq x \leq 10$ が $E I(x)=100$ 、 $2.5 \leq x \leq 7.5$ が $E I(x)=200$ であり、この剛性分布を梁 の各点のたわみや境界条件をモニターして同定する。 (計算法の検証が目的なので、ここでは単位系は無次 元としている.)

初めに、測定誤差がないものとして、正確なたわみ を与え、この曲け剛性分布を式 (3)により推定した結 果を図 1 に示す。前報でも示したように、十分な推定 結果が得られている。

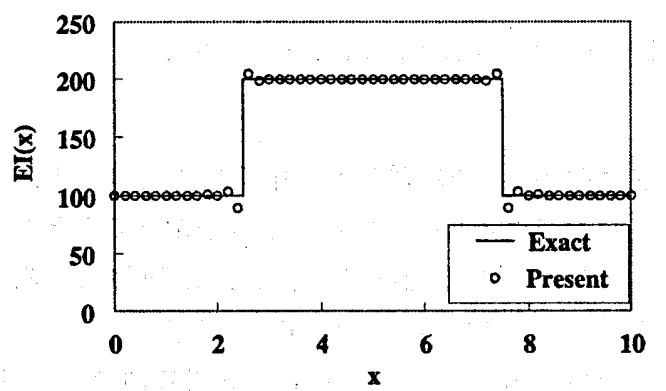

Fig. 1 Identification for a step beam

いっぽう、実際の場合を考えると、反力や曲げモー メントなどは理論的に計算できるとしても、たわみの 測定値は誤差を含むことを前提に、一定の誤差があっ ても精度よい安定した同定法の確立が肝要である。本 論文におけるアルゴリズムによれば、この誤差は連立 方程式 (4)の左辺の係数行列に影響する。

連立方程式を解くとき、各倸数の誤差が累積して、 A マトリックスのサイズの増大に連れて解が大きく変 動し不安定になることがありうる。この一例を図 $2 に$ 示す。ただし、各観測値には最大土 $1 \%$ の誤差を与え た。このように、未知数の数が增大すると解が大きく 変動する場合のあることがわかる。これらを解消する ための方策として、著者らは 2 つの方法を導入した。 すなわち、1．測定誤差のばらつきをなるべく抑える ために、測定值そのものではなく回帰曲線を用いるこ 之、2．ランクを低減し、安定化処理を行うこと、で ある。この安定化処理法は、再計算を伴うが、その一 般的な手順も構成した。

3.1 測定値の曲線回帰 測定值そのものよりも、 最小自乗近似により測定值の再帰曲線を作り、それを 用いる方が解の安定化にははるかに有効であることが わかった。ここでの計算によれば、回帰次数を 6 次以 上にしてもあまり改善は見られず、また6次近似の偏
差ノルムが最も小さいことがわかった。回帰次数が 6 次なら実用的でもあるので、一般的には 6 次の回帰曲 線で十分であろうと思われる。

3.2 ランク低減による解の安定化 図 2 に示さ れたように、未知数の数が少ないと係数マトリクスの 誤差に鈍感であり、連立方程式の解は比較的安定して いるが、段つき部などの剛性変化にも鈍感となる。そ こでモニタ一点を增やすと、連立方程式の解が大きく 変動し、不安定となることがわかる。実際にはこの兼 ね合いが難しい。図 3 はモニター点数が 21 とした場 合の同定結果である。この時、ランクを 11 と 9 に低減 したことにより安定した解が得られている。ただし、 段付部の剛性が急変する部分では再現性が鈍く、これ を改善するのが今後の課題である。

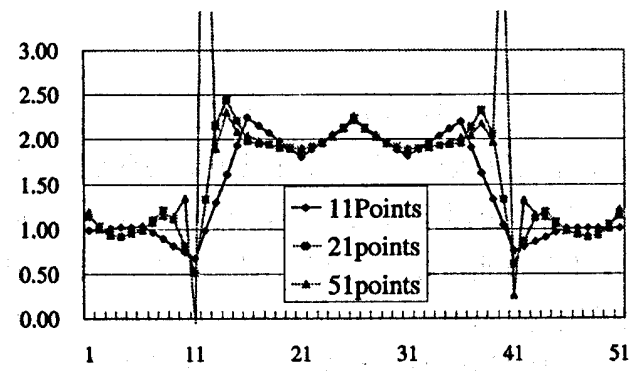

Fig. 2 Identification for a step beam with different number of $\mathbf{P}$

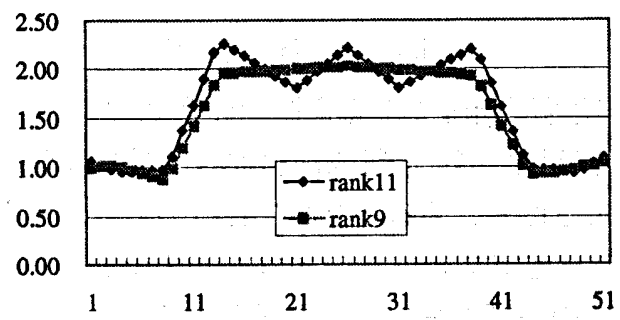

Fig. 3 Effect of decreasing the ranks for a stepped beam

\section{4. 結 言}

たわみの観測值からはりの曲け剛性分布を推定する 方法を構成し、測定誤差が存在する時の同定解の挙動 を定量的に調べるとともに、同定解が不安定になる現 象を解決する安定化処理について報告した。

$$
\text { 文 献 }
$$

（1）木須ほか, 一次元逆問題の境界要素法による新型解法, “機論”, 667 巻,61 号 A,(2001), pp.1423-1428

(2) 木須ほか, 離散積分法による梁の曲け用性の同定, 九州 支部講演論文集 No.028-1 pp.67-68 